\title{
Evidence on Trade Union Members' Dissatisfaction with Inequalities at a Scottish University
}

Dr. Theresa Marie Majeed

Assistant Professor, College of Business

Hawai'i Pacific University

Honolulu, Hawai'i, United States

E-mail: tmajeed@hpu.edu

\section{ABSTRACT}

\section{USA}

\begin{abstract}
The present paper includes insights on trade union members' perceptions of job dissatisfaction related to inequalities at a Scottish university. Research spanning more than five decades has consistently shown that trade union member employees report higher levels of job dissatisfaction than non-union employees, although industrial relations scholars have been unable to agree on as to why that is the case. Prior research of trade union membership and its link to job dissatisfaction has largely been quantitative. The present study therefore added much needed, individual-level insights to the industrial relations literature through its use of a qualitative approach that included interviews with 23 individuals. This research is part of a wider project in which trade union membership and job dissatisfaction were explored, and that led to the author being awarded a PhD from the University of St. Andrews in the United Kingdom.
\end{abstract}

\section{Keywords: Industrial relations, organizational behavior, job satisfaction, restructuring, higher education}

\section{Introduction}

Research of trade unions has long shown that trade union members report higher levels of job dissatisfaction than nonunion employees. Findings that suggest as much are in the works of Borjas (1979), Freeman (1980), Odwahn and Petty (1980), Freeman and Medoff (1984), Hersch and Stone (1990), Meng (1990), Miller (1990), Lincoln and Boothe (1993), Bender and Sloane (1998), Clark (1996), Heywood et al (2002), Renaud (2002), Bryson et al (2004), Guest and Conway (2004), Jones and Sloane (2009), Green and Heywood (2015), Haile (2015), Laroche (2016), and Laroch (2017), all of which used quantitative methods. The phenomenon has, therefore, received ample attention in the field of industrial relations. However, there is still no consensus across these works on why trade union members express such seemingly high levels of dissatisfaction with their jobs. Delbridge and Whitfield (2007:2178) have suggested that: "Effective research typically requires the bringing together of a range of methods that complement each other". The present study, therefore, contributes qualitative insights towards understanding an issue that previous quantitative studies have been unable to explain.

Insights on trade union members' job dissatisfaction are critical to understanding employee participation, or the focal debate in the field of industrial relations (Johnstone and Ackers, 2015). Yet, a puzzle underscores continued research into the topic, mainly because works that highlight the positive aspects of trade union membership seem contrary to the notion that trade union members are more dissatisfied with their jobs than non-union member employees. For example, trade unions are known to raise remuneration for their members (Nickell, 1977; Freeman and Medoff, 1984; Jarrell and Stanley, 1990; Miller and Mulvey, 1992; Booth, 1995; Delery et al, 2000; Arabsheibani \& Marin, 2001; Blanchflower and Bryson, 2004; Hirsch, 2004; Penca vel, 2009; West and Mykerezi, 2011; Long, 2013; Rios-Avila and Hirsch, 2014; Torm, 2014; Bryson and White, 2016), to improve terms and conditions of employment (Mitchell, 1983; Buchmueller et al, 2002; Budd and Mumford, 2004; Long, 2013; Goerke and Pannenberg, 2011), and to promote greater job control and participation in work-related decisions (Freeman, 1976; Freeman \& Medoff, 1984; Belonger, 1989; Gall, 2010; Lyness et al, 2012). There seems to be a contradiction, then, that invites the question of why trade union members would express dissatisfaction with their jobs.

This work is part of a wider project that sought to understand more about trade union membership and job dissatisfaction using two different case study organizations, a manufacturer and a university, in Scotland. The previous paragraph shows the rationale for why the project was initiated to better understand a research problem within the field of 


\author{
E-ISSN: 2469-6501 \\ VOL: 6, ISSUE: 1 \\ January/2020 \\ DOl:10.33642/fjbass.v6n1p4 \\ https://ijbassnet.com/
}

industrial, or the association between trade union membership and job dissatisfaction. That research problem is also discussed in the work of Majeed (2020), wherein results related to the manufacturer are revealed. The present work focuses on the part of the research project that pertains to reports from interviewees related to job dissatisfaction associated with inequalities at the university.

\title{
Literature Review
}

The concept of (in) equality is a central feature of trade union ideology and underscores trade union organizing behavior. To begin, trade unions are known to use the ideals of equal conditions and equal outcomes for all individuals to organize their members (Turner, 1986). In more recent work, equality is described as central to "the most significant development in British trade unionism of recent years: the increasing focus on organizing activity" (Simms et al, 2013, 1). Furthermore, those trade union organizing activities consist of "improving the representativeness of the union movement, particularly in relation to age, gender, ethnicity, and sectoral presence" (ibid: 5). The previous work highlights a relatively new development, however, as Freeman and Medoff (1984) suggest that trade unions have historically been the primary mechanism for working-class people. Those authors describe trade unions as social organizations that provide benefits to disadvantaged members of society:

"It is argued that though unions fight for self-interest legislation as do other groups in our pluralistic society they have scored their greatest political victories on more general social legislation and thus are more effective as a voice of the whole working population and the disadvantaged than as a vehicle for increasing the power of a monopoly institution". (ibid: 18)

Trade union membership in the UK has declined, however, as the working class has become more prosperous and no longer share in an identity that used to include poor standards of living or particular occupations (Kelly, 1998). The transition of trade unions from serving the interests of working-class individuals to promoting equality across historically marginalized groups of people has left a gap in what is known about the process(es) that underscore that transition. That gap exists, at least in part, because there is a dearth of research in the trade union literature towards understanding the intersection of social class and other forms of diversity (McBride et al, 2015). This work contributes evidence to help understand that transition and its relation to those processes, as it includes insights on equality gathered directly from trade union member employees of diverse backgrounds.

Furthermore, given that the workforce is increasingly diverse, it makes sense that trade unions are focusing their recruitment efforts on workers from underrepresented groups (Lindsay et al,2007) and working towards improving employment conditions for those groups (Munro, 2001). While trade union ideology has shifted to include issues such as discrimination and gender equality (Gregory and Milner, 2009), the reconfiguration of the trade union movement towards achieving equality for historically marginalized groups has not removed all of the obstacles that prevent these groups from gaining access to collective bargaining (Blackett and Sheppard,2003). Even after they join trade unions, blacks, women, disabled, and/or LGBTQ individuals may still be in a minority within their unions, as these individuals tend to possess unique characteristics that are not shared by the majority of trade union members (Humphrey, 2000). Yet, diversity includes individual-level dimensions in areas such as thought and communications (Lawrence and Weber, 2017) and it has been posited that including "more women, people of color, and gays and lesbians" in trade union leadership roles could lead to more creative ideas that could enable trade union revitalization (Kaminski and Yakura, 2008). It, therefore, bodes well that women have been able to assume more leadership roles in UK trade unions than previously was the case (Parker and Foley, 2010; Kirton, 2015), although the previously described works suggest there is still much work to be done towards helping women and/or individuals who identify with other minority groups.

Despite efforts made by trade unions to create more diverse membership bases, wider structural barriers that foster inequalities across organizations, in general, remain. Research has shown that women and individuals of color are paid less, on average, than white males (Lawrence and Weber, 2017). Indeed, the previous work suggests that white males have been shown to earn a third more than black males; just fewer than 20 percent more than white women; and over 30 percent more than black women (Ibid). Another work affirms that white males do indeed earn more than other ethnic groups, while also suggesting that 


\author{
E-ISSN: 2469-6501 \\ VOL: 6, ISSUE: 1 \\ January/2020 \\ DOl:10.33642/fjbass.v6n1p4 \\ https://ijbassnet.com/
}

the glass ceiling a commonly used term to describe an intangible barrier that prevents women and minorities from advancing into leadership roles is "a real barrier that is difficult to break" and "so subtle as to be hard to see" (Griffin, 2017: 84). All of this suggests that obstacles exist in workplaces so that white males, as a group, experience work differently than individuals who are excluded from that group.

\title{
Methodology
}

The ontological and epistemological assumptions that underscore the present work are based on the philosophy of phenomenology and interpreted using a social constructivist framework. The nature of reality and ontological approach of phenomenology suggests that there are multiple realities that vary according to individual experience (Moustakas, 1994, cited in Creswell, 2007: 18). Phenomenology is relevant to this research, as each trade union member interview has an interpretation of job dissatisfaction that is unique to them. Furthermore, the epistemic assumption is that individuals use their own perceptions to form objective meanings (Schutz,1967). Qualitative methods were used, as these can enable rich and deep analyses (Ackers et al, 2006; Brown et al, 2007; Timming, 2011). The use of qualitative methods in the present work, as previously noted, also enabled an original contribution to the industrial relations literature. Interviews were used in the present research, as they allow participants to discuss their personal views on topics (Kvale, 1996). Intensive and unscripted interviews each with duration of approximately one hour were employed here, as these permit researchers to delve deeper into responses (Charmaz, 2014).

The case study organization used in the present study is a university located in Scotland. Within the city in which it is located, it is considered one of the area's main employers. To gain access to the site, the researcher contacted four trade union representatives shown on the university's website and received a response from one, a female and a lecturer, who became the point of contact for and was the first interviewee in, the present study. When fieldwork was conducted in 2015 , there were approximately 3,000 employees at the site and the total number of trade union members was not disclosed. It is important to clarify that there were three trade unions at the university that represented different groups of employees: one trade union represented clerical and manual employees; another trade union represented technical employees, and the third trade union represented academics and academic-related employees. Because this study identified themes related to job dissatisfaction and not trade unions themselves, efforts were not made to differentiate between the trade unions themselves beyond a superficial level. In total, 23 individuals from diverse backgrounds and with unique personal characteristics, representing a wide range of occupational roles and located in different physical locations at the university, were interviewed for the present work. The researcher was unaware that restructuring was taking place at the university until the first interview was conducted. The restructuring is a major aspect of this work, emerging as it did in the responses of each interviewee. Furthermore, topics that emerged in interviews seemed to be supported by events that unfolded in the public eye after the project was completed, with particular emphasis on those that occurred in 2019, discussed later in this paper.

To better understand the results of the present work and the restructuring that affected the case study organization, one must have knowledge of the environment in which the case study organization was situated in 2015. At that time, the university operated in a competitive environment and its Principal and Vice-Chancellor one and the same individual had ambitions to increase the university's rankings. According to multiple interviewees, those ambitions were such that employees at the university received regular communications from senior management describing its mission to become the number one research university in Scotland. By all accounts, this was perceived as an overly-ambitious goal. Part of the competitive university environment in the U.K. included and to this day, still includes the Research Assessment Exercise, developed by the U.K. government during the 1980s, and later replaced by the Research Excellence Framework (or REF, as it is commonly known). The REF was used to rate the quality of research being produced at academic institutions and those ratings, in turn, were related to how much funding each academic institution received from the U.K. government. In simple terms, because the REF linked the quality of research produced by academics to the number of funds awarded to a given academic's employer, academics were under pressure to produce high-quality research because it was linked to their job security. Indeed, as part of the restructuring at the case study organization, the performance of its faculty and non-faculty employees was in the process of being reviewed during the time period in which fieldwork was conducted in 2015? Furthermore, when interviews were conducted, many faculty and staff had already been displaced, or made redundant, as a result of those performance reviews. 


\author{
E-ISSN: 2469-6501 \\ VOL: 6, ISSUE: 1 \\ January/2020 \\ DOl:10.33642/fjbass.v6n1p4 \\ https://ijbassnet.com/
}

It is important to note that in the analyses of the interview data, all of which were collected and transcribed by the researcher over a course of 7 months, themes were allowed to emerge. The researcher did not assume that dissatisfaction would be reported by interviewees. However, dissatisfaction did emerge in relation to inequalities at the university and the reports were overwhelmingly consistent. Furthermore, reports of dissatisfaction from interviewees at the university, in general, were strong; included candid and emotional responses at times; and showed that regardless of their physical location at the university, interviewees were aware of, and were dissatisfied with, similar issues.

\title{
Results
}

Trade union members at the university identified two main types of inequalities in this exploration. These were related to gender and to race, and both types of inequalities were associated with individuals facing challenges related to career progression. As evidence in this section will show, senior management was perceived by trade union member interviewees as having been biased in favor of white males. Dissatisfaction with gender inequalities is the first topic discussed here, as it was the most salient theme to emerge in interviews. To begin, one of the earliest individuals to be interviewed for the present work, a 65-year old Scandinavian professor, suggested that he was dissatisfied with the treatment of women at the university: "because, as they say, the little fridge magnet says you know, women have to work twice as hard to prove they're half as good. There's not enough diversity, there are not enough women in senior positions".

The previous responses were similar to those of another interviewee, a 57-year old white, British, female senior lecturer that identified herself as having a disability:

'There are a lot of women, but...there is no one above, a woman above the level of, of senior lecturer. We had a, a professor, a, two Deans ago, was a professor, so when I came, we had a woman professor. She left...the year after I came, and, which was replaced with a man. I'm actually coming to the end now of an appeal because my application for readership wasn't sent for external review. Um... and most people believe it should have been sent for external review. A man was promoted to the readership, but... as far as I'm aware; his CV isn't as...strong as my own CV. So I decided to, um...um, appeal. And I won the appeal".

As a member of the trade union branch committee, the previous interviewee was aware that she could appeal the decision that had prevented her application from being sent for external review. Thus, being in a trade union might have give $n$ her access to information that enabled her to understand her rights. Yet, she was also a senior lecturer with a record of publications that might have enabled her university to attract funding. Compared to her statements, the following responses help to show that inequalities might have different effects on female trade union member employees that are perhaps related to their location within an organization's occupational hierarchy. The next interviewee was a female trade union member who worked in administration and despite having received advice from an equality and diversity officer to take action in what seems like a straightforward case of potential discrimination, she did not.

The aforementioned female interviewee was 40-years old, held a lower-level administration position, and possessed a Masters's degree. She was white and from England, was an experienced professional, and had applied for a higher-level role within the university as an internal candidate. However, a recent male college graduate from an undergraduate program, with less work experience, got the position instead. She indicated that a trade union representative had advised her to take action, but she refused:

"I went for quite a senior, well it was in a, it was actually an academic-related post. And the person who got it...the man who got it...had been a student president. But basically, he was, he'd graduated...I think, the year before. And he'd done this, this presidency. Um, he got the post over my years and years of experience. Um, and I worked in a lot of different posts in this university and others. Um, and I really felt that...that was...I, I felt that was unfair. I didn't bring it up because...I think that if you do that, then you're just seen as a trouble maker. And um, so you just suffer in silence, basically. But funnily enough, and unprompted by me, I did speak, I was chatting to the, um... an equality and diversity officer, the university one. Um, about the interview and the post and, and who got it. And he raised his eyebrows and said that he thought that was, I should have questioned it. Um, there seems to be an implication that because they're a man, especially if they're married, you know they has got a family to support, you know. But...but it doesn't matter if a 


\author{
E-ISSN: 2469-6501 \\ VOL: 6, ISSUE: 1 \\ January/2020 \\ DOI:10.33642/ijbass.v6n1p4 \\ https://ijbassnet.com/
}

woman is a single parent, and has a family to support. Um, she's a, you know, she's sort of regarded as, well, a bit of a second-class citizen, I think. Um, I think it's also...kind glaringly obvious that although the university has a fantastic...policy on disability, ah, or access for students with disabilities, it um, employs...very, very few...members of staff with disabilities".

The responses above help to show that while female trade union member employees may be aware of their employment rights, it is not always the case that they will fight against discrimination, even under the assumption of trade union protection.

One of the leading trade union representatives at the university was a 53-year old white Scottish female lecturer. She was widely regarded as an expert in her field and was working on a high-profile investigation into a matter that was publicized in news outlets around the world at the time fieldwork was conducted for the present research. Her influence on the trade union members at the university was indicated in her statement: "to a large number of people, I am the trade union here". She expressed dissatisfaction with different kinds of inequalities, including racial inequalities ("there is an overwhelmingly white staff here") and gender inequalities. In hindsight, the following responses from her seem to highlight both inequalities within the system that was present in 2015 , as well as issues that may have contributed to a governance scandal that unfolded at the university years later in 2019:

"Um, we have a situation in this university as we do, as, as happens across the board in all industries... where women are very often, um, at, at, in the lower levels of the institution, we have a lot of women. So, if you look at the grading, and I've actually seen all the figures, because as, as, as a trade union representative, I've seen all the equality data. Um, we have a kind of graph... where...the higher up the scale you get, the fewer women there are. The lower down the scale, the more women there are. There's an understanding that that is a problem. That, that equality, em, gender equality is a problem. But, what ultimately happens is...you go up towards, and, and, and the ultimate, em, decisionmaking body in this university is university court... and we, on court...have a very serious gender balance issues. Um...mostly it's very serious because there isn't really that much acknowledgment that it's a problem. Some, certainly the executive staff...so principle and, and his kind of team of vice principals. They understand that it's a problem. But they are all mean. Um, but you know so we've got this situation where there, there are a lot of men at the top saying yes, we really need to get more women in. But they're not actually willing to do anything to change it. So for example, if, if, someone was to suggest some kind of positive discrimination, immediately, the old silly arguments set in, oh, but, but women want to be in a job because they're, em...the best person for the job. To which my, my answer is always...I do not believe for one second that all the men around this table are only here because they were the best person for the job. The majority of you are here because you're men".

The responses above enable interesting insights into positive discrimination and preferential treatment, as well as awareness of inequalities. Her responses related to positive discrimination suggested that the principal and his team of viceprincipals were either largely ignorant of the issues that female employee experienced at the university in relation to discrimination, or that preferential treatment enabled white males to occupy senior management positions at the university over other non-white and/or non-male individuals. Given the events that unfolded in 2019, discussed later in this paper, it seems all the more likely that preferential treatment by senior management an issue that surfaced repeatedly in different interviews was, in fact, a serious problem at the university in 2015.

The acting president of the academic trade union, a 50-year old white and British male, expressed dissatisfaction with racial inequalities: "In my role as a trade unionist, I meet management on another basis, and this is where I see lots of people being promoted who, who, because, you know, their face fits rather than their potential to do the job better than somebody else". He indicated that the selection process for redundancies had excluded white Scottish males specifically:

"And...there was only one.... white...Scottish male. Out of the twenty people, who were selected to be made at risk of redundancy? The other...nineteen...were all of the different backgrounds. And, even though something likes sixty percent were white, Scottish male...the selection criteria seemed to have biased that the people who were selected for being at risk of redundancy weren't white Scottish male. And that and that shock me". 


\author{
E-ISSN: 2469-6501 \\ VOL: 6, ISSUE: 1 \\ January/2020 \\ DOI:10.33642/fjbass.v6n1p4 \\ https://ijbassnet.com/
}

WWW.cpernet.org

The next topic responses included here are from a trade union equality and diversity officer. She was a 45-year old native of Scotland, disclosed to the researcher that she was disabled, and worked as a director in student services. According to her, inequalities included many dimensions:

"I think I'm at a disadvantage because I'm a female, I have disabilities, and I'm a trade union rep. Um, it's a too white male. I should know all the statistics off the top of my head, cuz I'm the equality and diversity officer for Scotland. Em...particularly when you get to higher grades, most people...you meet are white British males. Now I think that's symptomatic of a longstanding cultural economic issue. Em, the women who, that I'm aware of, who have kind of broken that glass ceiling, tend to be white British, or um, European. So...running alongside that, you've got all the individual egos who are jostling for position and...you know, well, they've been principal's best friend, so then they get put higher and, you know. Dean's jobs or higher academic jobs, em, who are useless, feckless, um...horrid individuals. And I'm being positive".

A 60-year old white Scottish male security guard and lay trade union member expressed his dissatisfaction with racial inequalities according to his observations of security personnel: "people of color...oh well; surely there must be somebody...who's ethnically different from me, and should be looking for a job, which would be better". He had employed at the university, and in the trade union, for 27 years.

Next, a male interviewee, aged 26 and a native of Pakistan described racial discrimination in much greater detail:

"And, like, based on...not my experience, but a lot of people that I went to university with like, you know, people from ethnic backgrounds and all that, um...they, they applied to loads of jobs here, ah, never got shortlisted. Right, and, like some of them were like overqualified, or like super qualified properly, but... and no feedback. I mean, one of them got rejected for an internship, and, like, and it's just...it's just, I think it's just individual bias that people have or whatever, in the recruitment process, I, I mean, I don't think they are as diverse as other universities are".

The aforementioned interviewee also expressed dissatisfaction with his not having been promoted in the business affairs office. He indicated that rules were applied differently to different people and that some employees had been promoted into positions created especially for them at the university. When he asked his managers if a position could be created for him, he was told that the university no longer allowed it. Thus, he felt that he had been treated unfairly, although he had not complained to his trade union about the situation. It is important to note that he was one of at least five non-white, non-U.K. native interviewees who visibly held back tears while talking to the researcher. There was, it seemed, a certain degree of bravery shown by some interviewees in their disclosures.

The last statements included in this section are from a trade union representative. He was a 56-year old white Scottish male in a director-level, technical services position. He helped to shed light on wider structural inequalities as he mentioned the concept of a class system. His responses were unique, as most interviewees did not describe a class system in their interviews. As his statements seem to suggest, the very senior management was at the top of the U.K. academic class system:

"In academia, I think in general, um...hierarchy is very prevalent, because we have at the very top, perhaps the principal, and you have at the top end the cleaner. I'm sorry, the bottom ends the cleaner. Um, and everywhere in between, there are people there who constantly try to understand their role in it, because if they're insecure, it reinforces their position in the pecking order, to understand where they fit. Most of the...problems I experience come from people who are insecure, who don't quite know how to perceive themselves. What I've experienced, is that very senior management tend not to...be, be difficult in this way, it's a...in our culture in the U.K., we, we have, we call it, we refer to it as the class system. Um, and the very, very senior management are usually...not affected by this, because they're comfortable with who they are".

\title{
Discussion and conclusion
}

Trade union members expressed dissatisfaction with a variety of inequalities at the university. However, the most prevalent topics discussed by interviewees, in general, were related to gender and ethnicity. Gender inequalities included potential discrimination against women, who seemed to have been denied access to senior positions at the university. Senior positions at the university, most interviewees suggested, were mainly filled by males. Racial inequalities included the idea that 


\author{
E-ISSN: 2469-6501 \\ VOL: 6, ISSUE: 1 \\ January/2020 \\ DOl:10.33642/fjbass.v6n1p4 \\ https://ijbassnet.com/
}

(C) Center for Promoting Education and Research (CPER) USA

WWW.cpernet.org

senior positions were filled by white males and that non-whites were excluded from senior management roles. Each of the two previously mentioned personal attributes gender and race were strong factors that emerged across interviews in relation to career advancement. Consistently, interviewees indicated that non-white and/or female employees at the university had difficulty advancing in their careers. Yet, some individuals who had recounted first-hand experiences of having been denied promotional opportunities remained silent while others did not, despite having the awareness that they had trade union protection. It, therefore, seemed likely that power, perhaps derived as a result of one's occupational status, might have been a factor in whether female and/or non-white trade union member employees were willing to seek help.

In 2019, following the completion of the study that underscores the present work; an attempt was made at the university to hire new leadership. The individual that was ultimately hired was white, British, and a professor. Vast sums of money were spent to attract the individual to the university: the individual received free living quarters and a controversial compensation package. However, the individual's tenure as leader of the university lasted for less than one year and was enveloped in scandals on multiple fronts: accusations of bullying had been levied against the individual by employees at the university; the individual was alleged to have violated a financial contract with a party external to the university, but within the university's city; and it seemed that an exorbitant sum had been paid to a search firm to recruit the individual, despite the university's having been in difficult financial circumstances. It was not clear how the search firm or the individual that was hired into the leadership position had been authorized to receive so much of the university's funds especially, as this work suggests, the university had recently undergone a restructuring in which many employees had been made redundant. All of this took place, again, in the public eye.

When added to the insights gained from 2015, the more recent data from 2019 seems to affirm the responses included in the results section of the present research, as well as previous works in the literature review at the beginning of this paper. The glass ceiling, it seems, is real. Furthermore, it applies to non-whites and/or minority employees, who face intangible obstacles and challenges to advancing their careers. These obstacles include bias on the part of other members of the organizations that they work in, as well as the bias that is deeply embedded within wider environmental structures. In this particular paper, the actions of senior managers seemed beyond reproach within the class system in the U.K. What is especially interesting about the events of 2019 is how they seem to address the present study's original key limitation, in that data was not gathered from senior management. Given that the governance issue at the university is now a known issue in the public domain, it seems reasonable to suggest that much of that limitation has been overcome. Interviews, it seems, would not likely have captured an honest picture of senior management at a point in time in 2015. Rather, their actions and behaviors had to speak for themselves over time, so that the public could bear witness and pass judgment based on more substantial facts.

Society in the U.K. is clearly changing and further research will be needed to understand the effects of those changes on more vulnerable members of the workforce, or those who do not identify with majorities in the workplace. As more events unfold in the U.K. largely in relation to Brexit at present more insights will be needed from those individuals who would otherwise remain silent. Rather than waiting for time to reveal the truth, the present author recommends that researchers seek it out proactively if only to break the silence.

\title{
References
}

Ackers, P., Marchington, M., Wilkinson, A. and Dundon, T. (2006). Employee participation in Britain: from collective bargaining \& industrial democracy to employee involvement \& social partnership — two decades of Manchester/Loughborough research. Decision, 33:1, 75-88.

Arabsheibani, G.R. \& Marin, A. (2001). Union membership and the union wage gap in the U.K. Labour, 15:2, $221-236$.

Belonger, J. (1989). Job control and productivity: New evidence from Canada. British Journal of Industrial Relations, 27:3, 347-364.

Bender, K.A. and Sloane, P.J. (1998). Job satisfaction, trade unions, and exit-voice revisited. Industrial and Labor Relations Review, 51:2, 222-240. 
Blackett, A. \& Sheppard, C. (2003). Collective bargaining and equality: Making connections. International Labour Review, 142:4, 419-457.

Blanchflower, D.G. \& Bryson, A. (2010). The wage impact of trade unions in the UK public and private sectors. Economica, 77, 92-109.

Booth, A.L. (1995). The economics of the trade union. Cambridge: Cambridge University Press.

Borjas, G.J. (1979). Job satisfaction, wages, and unions. Journal of Human Resources, 14:1, 21-40.

Brown, A., Charlwood, A. and Spencer, D.A. (2012). Not all that it might seem: why job satisfaction is worth studying despite it being a poor measure of job quality. Work, Employment and Society, 26:6, 1007-1018.

Buchmueller, T.C., Dinardo, J. and Valletta, R.G. (2002). Union effects on health insurance provision and coverage in the United States. Industrial and Labor Relations Review, 55:4, 610-622.

Budd, J.W. and Mumford, K. (2004). Trade unions and family-friendly policies in Britain. Industrial and Labor Relations Review, 57:2, 204-222.

Bryson, A., Cappellari, L. and Lucifora, C. (2004). Does union membership really reduce job satisfaction? British Journal of Industrial Relations, 42:3, 439-459.

Bryson, A. and White, M. (2016). Unions and the economic basis of attitudes. Industrial Relations Journal, 47:4, 360-378.

Charmaz, K. (2014). Constructing grounded theory, 2nd ed. Sage Publications Ltd. London; Thousand Oaks, CA.

Clark, A.E. (1996). Job satisfaction in Britain. British Journal of Industrial Relations, 34:2, 189-217.

Delbridge, R. and Whitfield, K. (2007). More than mere fragments? The use of the Workplace Employment Relations Survey data in HRM research. International Journal of Human Resource Management, 18:12, 2166-2181.

Delery, J.E., Gupta, N., Shaw, J.D., Jenkins, Jr., G.D., and Ganster, M.L. (2000). Unionization, compensation, and voice effects on quits and retention. Industrial Relations, 39:4, 625-645.

Freeman, R.B. (1976). Individual mobility and union voice in the labor market. American Economic Review, 66:2, $361-368$.

Freeman, R.B. (1980). The exit-voice tradeoff in the labor market: Unionism, job tenure, quits, and separations. Quarterly Journal of Economics, 94:4, 643-673.

Freeman, R.B. and Medoff, J.L. (1984). What Do Unions Do? New York: Basic Books, Inc.

Gall, G. (2010). Labour union responses to participation in employing organizations. In P.J. Gollan, D. Lewin, M. Marchington, M., \& A.Wilkinson (Eds.). The Oxford Handbook of Participation in Organizations, New York: Oxford University Press.

Goerke, L. \& Pannenberg, M. (2011). Trade union membership and dismissals. Labour Economics, 18:6, 810-821.

Green, F. and Heywood, J.S. (2015). Dissatisfied union workers: Sorting revisited. British Journal of Industrial Relations, 53:3, 580-600.

Gregory, A. and Milner, S. (2009). Trade unions and work-life balance: changing times in France and the U.K.? British Journal of Industrial Relations, 47:1, 122-146.

Griffin, R.W. (2017). Management. (12th ed). Boston: Cengage Learning.

Guest, D.A. \& Conway, N. (2004). Exploring the paradox of unionized worker dissatisfaction. Industrial Relations Journal, 35:2, 102-121.

Haile, G.A. (2015). Workplace job satisfaction in Britain: evidence from linked employer-employee data. Labour, 29:3, 225242.

Hersch, J. and Stone, J.A. (1990). Is union job dissatisfaction real? Journal of Human Resources, 25:4, p. 736-751. 
Heywood, J.S., Siebert, W.S., and Xiangdong, W. (2002). Worker sorting and job satisfaction: The case of union and government jobs. Industrial and Labor Relations Review, 55:4, 595-609.

Hirsch, B.T. (2004). Reconsidering union wage effects: Surveying new evidence on an old topic. Journal of Labor Research, 25:2, 233-266.

Humphrey, J.C. (2000). Self-organization and trade union democracy. The Sociological Review, 48(2), $262-282$.

Jarrell, S.B. and Stanley, T.D. (1990). A meta-analysis of the union-nonunion wage gap. Industrial Relations: Theory and Practice in Britain. Blackwell Publishers, Ltd. Oxford: UK.

Johnstone, S. \& Ackers, P. (2015). Introduction: employee voice. In S. Johnstone \& P. Ackers (Eds.). Finding a voice at work: new perspectives on employment relations (pp. 1-17). Oxford: Oxford University Press.

Jones, R.J. \& Sloane, P.J. (2009). Regional differences in job satisfaction. Applied Economics, 41, 1019-1041.

Kaminski, M. and Yakura, E.K. (2008). Women's union leadership: closing the gender gap. The Journal of Labor and Society, $11: 4,459-475$.

Kelly, J. (1998). Rethinking industrial relations: Mobilization, collectivism and long waves. Routledge, London: UK.

Kirton, G. (2015). Progress towards gender democracy in UK unions 1987-2012. British Journal of Industrial Relations, 53:3, 484-507.

Kvale, S. (1996). Interviews: an introduction to qualitative research interviewing. Sage Publications, Inc. Thousand Oaks, CA. Laroche, P. (2016). A meta-analysis of the union-job satisfaction relationship. British Journal of Industrial Relations, 54:4, 709-741.

Laroche, P. (2017). Union membership and job satisfaction: Initial evidence from French-lined employer-employee data. Human Resources Management Journal, 27:4, 648-668.

Lawrence, A.T. and Weber, J. (2017). Business and society: stakeholders, ethics, public policy. (15th ed). New York: McGraw-Hill Education.

Lincoln, J.R. and Boothe, J.N. (1993). Unions and work attitudes in the United States and Japan. Industrial Relations, 32:2, 159-187.

Lindsay, C., Munro, A. and Wise, S. (2007). Making equalities work? Scottish trade unions' approaches to equal opportunities. Equal Opportunities International, 26:5, 465-481.

Long, G.I. (2013). Differences between union and nonunion compensation, 2001-2011. Monthly Labor Review, 136:4, 16-23.

Lyness, K.S., Gornick, J.C., Stone, P., and Grotto, A.R. (2012). It's all about control: Worker control over schedule and hours in cross-national context. American Sociological Review, 77:6, 1023-1049.

Majeed, T.M. (2020). Evidence on Scottish trade union members' job dissatisfaction. Global Journal of Business Research, 14(1).

McBride, A., Hebson, G. and Holgate, J. (2015). Intersectionality: are we talking enough notice in the field of work and employment relations? Work, Employment \& Society, 29:2, 331-341.

Meng, R. (1990). The relationship between unions and job satisfaction. Applied Economics, 22, 1635-1648.

Miller, P.W. (1990). Trade unions and job satisfaction. Australian Economic Papers, 29:55, 226-248.

Miller, P. and Mulvey, C. (1992). Trade unions, collective voice and fringe benefits. Economic Record, 68(2), $125-141$.

Mitchell, D.J.B. (1983). The 1982 union wage concessions: A turning point for collective bargaining? California Management Review, 25:4, 78-92. 
Moustakas, C. (1994). Phenomenological research methods. Thousand Oaks, CA: Sage. As cited in: Creswell, J.W. (2007). Qualitative inquiry and research design: choosing among 5 approaches. (2nd ed). Thousand Oaks, CA: Sage Publications.

Munro, A. (2001). A feminist trade union agenda? The continued significance of class, gender and race. Gender, Work \& Organization, 8:4, 454-471.

Nickell, S.J. (1977). Trade unions and the position of women in the industrial relations wage structure. British Journal of Industrial Relations, 15:2, 192-210.

Odewahn, C.A. and Petty, M.M. (1980). A comparison of levels of job satisfaction, role stress, and personal competence between union members and non-members. Academy of Management Journal, 23:1, 150-155.

Parker, J. and Foley, J. (2010). Progress on women's equality within UK and Canadian trade unions: Do women's structures make a difference? Industrial Relations, 65:2, 281-303.

Pencavel, J. (2009). How successful have trade unions been? A utility-based indicator of union well-being. Industrial and Labor Relations Review, 62:2, 147-156.

Renaud, S. (2002). Rethinking the union membership/job satisfaction relationship: Some empirical evidence in Canada. International Journal Manpower, 23:2, 137-150.

Rios-Avila, F. \& Hirsch, B.T. (2014). Unions, wage gaps, and wage dispersion: New evidence from the Americas. Industrial Relations, 53:1, 1-27.

Schutz, A. (1967). The phenomenology of the social world. Translated by George Walsh and Frederick Lehnert. With an introduction by George Walsh. Evanston, Illinois: Northwestern University Press.

Simms, M., Holgate, J., and Heery, E. (2013). Union voices: Tactics and tensions in U.K. organizing. ILR Press: NY.

Timming, A.R. (2011). What do tattoo artists know about HRM? Recruitment and selection in the body art sector. Employee Relations, 33: 5, 570-584.

Torm, N. (2014). The role of trade unions in Vietnam: A case study of small and medium enterprises. Journal of International Development, 26:2, 207-221.

Turner, B.S. (1986). Equality. Ellis Horwood: Chichester.

West, K.L. \& Mykerezi, E. (2011). Teachers' unions and compensation: The impact of collective bargaining on salary schedules and performance pay schemes. Economics of Education Review, 30:1, 99-108. 